\title{
Institutional Entrepreneurship and Agency
}

\author{
Elke Weik \\ University of Leicester \\ School of Management \\ Leicester LE1 7RH \\ UK \\ phone: 0044-116-252 5318 \\ email: e.weik@le.ac.uk
}

Key words: institutionalist sociology, institutional entrepreneur, institutional work, agency, managerialist bias, functionalism, practice

Word count: 6911 


\title{
Institutional Entrepreneurship and Agency
}

\begin{abstract}
The notion of institutional entrepreneurship has become very popular in the last decade. Starting from a review of the literature on the topic, I first focus the use of the idea of individual entrepreneurs and point out three theoretical incongruities it produces. I then discuss notions of collective entrepreneurship and institutional work to see if they can overcome these incongruities. I conclude that although they can remedy some of the problems, these notions run the risk of describing everything until they describe nothing. In order to limit and enable the entrepreneurship literature to discuss agency meaningfully, I argue, it needs to develop analytical frames of agency derived either from existing sociological theories or from further developing its own brand of agency theory.
\end{abstract}


The concept of institutional entrepreneurship has attracted a lot of interest in institutionalist sociology. Hardy and Maguire (2008:198) refer to a “rapidly growing body of organizational research". In their introduction to a special issue on the topic in "Organization Studies", Garud et al (2007:957) mention that it attracted a record number of submissions. Most recently, Leca, Battilana and Boxenbaum (2008) have documented a rise of publications on the topic in peer-reviewed journals to almost 20 per year for 2007. The concept is supposed to fulfil a number of functions, most prominently to (re-)introduce agency to institutionalist sociology (Battilana 2006; Beckert 1999; Garud, Hardy and Maguire 2007; Hardy and Maguire 2008; Lounsbury and Crumley 2007; Mutch 2007). This gives authors the opportunity to explain change endogenously (Battilana 2006; Greenwood and Suddaby 2006) and to emphasise the role of power and politics in institutional change (Garud, Hardy and Maguire 2007; Levy and Scully 2007; Zilber 2007).

The popularity indicates a certain usefulness of the concept either in theoretical or publication-related respects. As often happens with popular concepts, however, I believe the notion of the institutional entrepreneur has been employed to pull too many wagons and has, for this reason, become meaningless. To substantiate my claim, I initially conducted a qualitative, NVivo-based analysis of 23 major publications on the topic (see table 1) between 1999 and 2007 to see how the concept is defined and used in the analysis of institutional change. This research has in the meantime been overtaken by a more inclusive study of 67 book chapters and articles on the notion between 1988 and 2008 (Leca, Battilana and Boxenbaum 2008). While focussing on slightly different issues, there is enough overlap with my own review to draw on the results of this second study as well. I have, in a third step, also mapped more recent publications on the notion up to 2010. 
My subsequent critique highlights some shortcomings and theoretical incongruities that are, I argue, due to a lack of a theory of agency in the entrepreneurship literature. In the following sections, I will first examine how the concept of agency and agents is used in the body of literature referred to above. I will then point out two problems - a managerialist-individualist bias and a conflation of practice and action - that can be addressed by abandoning the notion of individual entrepreneurs. Subsequently, I will discuss whether the notions of collective entrepreneurship or institutional work can produce better results.

\section{The concept of agency in the entrepreneurship literature}

The majority of scholars in my initial study refers to entrepreneurs as creators of institutions (Child, Lu and Tsai 2007; Clemens and Cook 1999; Fligstein 2001; Garud, Hardy and Maguire 2007; Garud, Jain and Kumaraswamy 2002; Levy and Scully 2007; Lounsbury and Crumley 2007; Mutch 2007; Perkmann and Spicer 2007; Wijen and Ansari 2007; Zilber 2007). Second comes a group that looks at entrepreneurs' roles in institutional change, i.e. the destruction of one institution and the establishment of another. Of comparatively marginal interest are entrepreneurs that are maintaining institutions (Fligstein 2001; Zilber 2007) or that

are solely destroying institutions (Maguire and Hardy 2009). Especially research in the latter form is quite recent. This distribution fits Schumpeter's notion of an entrepreneur as creator or creative destroyer, which we are going to discuss later on in the paper.

If we are looking at how institutional entrepreneurs are characterised, we find that the majority of authors sees them as agents pursuing certain interests and acting strategically (Beckert 1999; Child, Lu and Tsai 2007; Fligstein 2001; Garud, Hardy and Maguire 2007; Greenwood and Suddaby 2006; Lawrence and Phillips 2004; Levy and Scully 2007; 
Misangyi, Weaver and Elms 2008; Wijen and Ansari 2007). This is in line with DiMaggio’s initial formulation and his emphasis on human interest: "New institutions arise when organized actors with sufficient resources (institutional entrepreneurs) see in them an opportunity to realize interests that they value highly” (1988:14). With regard to their concrete actions, we find that entrepreneurs mobilise resources (Battilana 2006; Beckert 1999; Garud, Hardy and Maguire 2007; Khan, Munir and Willmott 2007; Levy and Scully 2007; Misangyi, Weaver and Elms 2008; Mutch 2007; Zilber 2007) and mobilise other actors (Beckert 1999; Fligstein 2001; Garud, Hardy and Maguire 2007; Khan, Munir and Willmott 2007; Levy and Scully 2007; Lounsbury and Crumley 2007; Perkmann and Spicer 2007; Suddaby and Greenwood 2005; Wijen and Ansari 2007; Zilber 2002), again in line with DiMaggio’s (1988) initial concerns. The mobilisation of others also draws on Fligstein's (2001:106) definition of socially skilled actors: “The ability on the part of actors to analyze and attain such cooperation can be viewed generically as social skill”. A third aspect is the idea that entrepreneurs create meaning (Garud, Jain and Kumaraswamy 2002; Misangyi, Weaver and Elms 2008; Perkmann and Spicer 2007; Rao and Giorgi 2006; Suddaby and Greenwood 2005; Zilber 2007), which is derived from Zilber’s (2002) seminal work on the role of meaning in institutional agency. Other descriptions, for example institutional entrepreneurs as leaders (Child, Lu and Tsai 2007; Levy and Scully 2007; Wijen and Ansari 2007), visionaries (Beckert 1999; Perkmann and Spicer 2007; Rao and Giorgi 2006; Zilber 2007) or reflexive agents (Beckert 1999; Greenwood and Suddaby 2006; Mutch 2007) play a rather minor role.

This very general characterisation of institutional entrepreneurs justifies Mutch's critique that "the concept tends to describe the phenomenon under inspection rather than analysing it, leaving assumptions about the nature of agency unexamined...” (Mutch 2007:1123) 
In response to this, one might argue that not every sociological theory needs a unique concept of agency but can draw on existing ones. There is, however, no common denominator in the field. The authors most often cited with regard to agency in my study are DiMaggio and Fligstein, trailed by Giddens (1984) and the "Schütz light” version of Emirbayer and Mische (1998). DiMaggio himself does not explicitly refer to an action theory, while Fligstein quotes symbolic interactionism (Mead, Goffman, Joas) and, for certain aspects, Giddens. A review of the theoretical papers in the study of Leca et al. (2008) shows roughly the same picture, except that Bourdieu draws equal with Giddens and Emirbayer and Mische. Among them, it is only Emirbayer and Mische who are used to explore agency as such, while Bourdieu often only serves to provide the notion of the field, Giddens the notion of structuration.

Let us note at this point that none of these action theories has a systematic place for "the entrepreneur” as a special type of agent. This notion is derived from a different theoretical school. We will discuss this problem shortly. Secondly, all these action theories point to reflexivity as an important ingredient of agency. This ingredient, however, seems to get lost quite quickly in the institutionalist discussion of agency, as can be shown for the discussion of the so-called "paradox of embedded agency".

This "paradox of embedded agency" is a quite peculiar feature of the institutional entrepreneurship literature (Battilana 2006; Battilana and D'Aunno 2009; Beckert 1999; Dorado 2005; Garud, Hardy and Maguire 2007; Greenwood and Suddaby 2006; Levy and Scully 2007; Wijen and Ansari 2007). It can be formulated as: How can actors change institutions if they take them for granted and thus cannot envision alternatives? I think that the paradox, which is widely discussed, is quite revealing of a certain naiveté in the conceptualisation of actors and definitely omits any reference to a reflexive actor in its formulation. It has been observed correctly that the paradox alludes to the perennial structure- 
agency debate in social theory (Battilana and D'Aunno 2009; Garud, Hardy and Maguire 2007; Wijen and Ansari 2007). Thus, it would be presumptuous to expect any definite answers. To formulate the structure-agency opposition as a paradox, however, shows a quite surprising ignorance of at least three decades worth of debates in social theory. However, to give institutionalist authors their due, on closer inspection the so-called "paradox" tends to be resolved within the next three sentences of each article mentioning it, normally with reference to Giddens. Apart from the fact that this quick resolution makes the emphasis on "paradox" look quite ridiculous, we may note that Giddens approaches the problem in quite a different way. In his discussion of agency, Giddens (1984:chap.2) relies heavily on unintended consequences to explain why practices are reproduced. Entrepreneurial action, however, as we have seen above, is normally characterised as planned, intentional and strategic. Giddens's strategic conduct (Giddens 1984:288ff.), on the other hand, represents a mode of analysis involving a "bracketing" of the production of structural properties rather than a conception of agency. It concerns the ever-present "action side” of the structuration process. It hence refers to an ongoing activity more in line with the concept of institutional work (DiMaggio 1988; Maguire and Hardy 2009; Perkmann and Spicer 2007) than with single acts of entrepreneurship. In terms of content, Giddens stresses three tenets for the analysis of strategic conduct: “the need to avoid impoverished descriptions of agents' knowledgeability; a sophisticated account of motivation; and an interpretation of the dialectic of control” (Giddens 1984:289). In the institutionalist literature, some authors follow Giddens’s lead in stressing entrepreneurs’ reflexivity (Garud, Hardy and Maguire 2007; Mutch 2007; Seo and Creed 2002), while entrepreneurs' motivation (Greenwood and Suddaby 2006) or the control aspect (Levy and Scully 2007) remains definitely underrepresented.

However, we also find two strands that lead into a quite different direction. In one, Beckert (1999) uses Giddens’s stress on the choices knowledgeable actors make as an opportunity to 
introduce a rational actor perspective (in a similar vein, Dorado 2005). This return of the rational actor is even more surprising if we recall the very first line of DiMaggio's landmark article: "Institutional theories of organization represent an important break with ration-actor models...” (DiMaggio 1988:3). So a movement that has started with DiMaggio's and Fligstein's attempts to bring agency into a theory with hitherto strong structuralist overtones and a wealth of historical and cultural data ends up with the homo oeconomicus. It also confirms Mutch's suspicion that the theoretical indeterminacy of agency in institutionalist theory permits "smuggling elements of the rational actor model back in through the back door” (Mutch 2007:1124). We shall come back to the rational actor in a minute.

In a second strand, Battilana reasons that in order to link individual agency and organisational or societal structures, we have to "explain under which conditions individuals are enabled to act as institutional entrepreneurs” (Battilana 2006:654). Battilana’s argument echoes a very prominent concern in the institutional entrepreneurship literature. It refers to the question which conditions "produce" entrepreneurs, i.e. either trigger entrepreneurial behaviour or make it successful. I will come back to these enabling conditions later on. For now, it should be noted that, although the authors do not seem to be aware of this, the concept of "conditions" is different from a reciprocal interdependence of structure and agency as suggested by structuration theory. It is a much more linear argument progressing from a status quo ante (with enabling conditions) to entrepreneurial action changing this status quo. This represents either a classical structuralist view on agency - thus breaking with Schütz, Mead, Goffman or Giddens - or a very reduced form of Giddens’s "bracketing” without any of the tenets that Giddens thought important. In its linearity, it is in fact closer to the theoretical notion of the entrepreneur, which we will discuss now. 


\section{Schumpeter's entrepreneur}

Although much of Schumpeter's (1934) discussion focuses on the function of the entrepreneur (Unternehmer), he categorizes entrepreneurship as a type of behaviour. The entrepreneur realises new possibilities and combinations. Accordingly, his major faculty is not the intellect but the will. In contrast to the inventor, who creates a possibility per se, the entrepreneur's activity refers to the practical actualisation. He is also characteristically involved in new ventures and non-routine situations and typically meets with social resistance of those who want to defend the status quo. For this reason, founding a normal company in a normal economic environment does not count as entrepreneurial activity. Entrepreneurial activity has to map unknown terrain, to move where no-one dared venture before. It is, furthermore, not restricted to capitalist economies. Schumpeter cites socialist functionaries as well as feudal lords and tribal chiefs as examples of potential entrepreneurs. Their prime motif is not consumption or more generally an immediate enjoyment of the created value. The entrepreneur "creates restlessly because he cannot do otherwise" (Schumpeter 1934:137). Be it the satisfaction of founding a private power realm, the will to win, or the simple joy of creation, in all cases the entrepreneur acts in an economically non-rational way because his marginal costs are greater than his marginal gains. As creation is a limited process, however, entrepreneurship cannot be a permanent attribute of a person but, as stated above, a type of behaviour occurring from time to time.

Schumpeter's entrepreneur is an individual human being with a strong will and the (practical) knowledge to spot opportunities. He states quite clearly that this person does not need, indeed often lacks, intelligence, charisma or a high social position. The entrepreneur seems, in fact, not dependent on any form of social life except economic exchange. "He is typically [...] a parvenu and without tradition, hence often insecure, adaptive, afraid - everything but a leader 
- outside of his bureau. He is a revolutionary of the economy...” (Schumpeter 1934:130) “revolutionary” here with the connotation of being quite smelly, unrefined chaps. As an economist, Schumpeter is more interested in the functional aspects of entrepreneurship than in the sociological or psychological side. His repeated use of the word "type" and his emphasis on the analytical nature of the entrepreneurial character (i.e. the fact that it is always mixed with other types of behaviour) make his entrepreneur resemble Weber’s ideal types.

If we compare this entrepreneur with our previous discussion of the agent in institutionalist theory, we note that Schumpeter's entrepreneur is always a single human being acting strategically and, most importantly, creatively insofar as he realises hitherto unknown or unused potentials. Schumpeter's approach is, moreover, clearly functionalist without any concern for contingencies in the context of action, i.e. the organisational or institutional field.

\section{Individualist-Managerialist bias}

Hence, importing the notion of the entrepreneur in institutionalist theory introduces a functionalist conception of a strategic individual actor. The notion of the entrepreneur, however, is not restricted to scholarly analysis, but can be regarded as one of capitalism's core terms. As such, it carries strong positive and emotionally laden connotations in the popular imagination. The entrepreneur is the hero, the problem-solver, the one who does what must be done, even in adverse conditions, the creative destructor, the carrier of progress. He (or seldom she) is the free will and the free spirit in a free market. Hence stories of institutional entrepreneurship are usually stories of success (Khan, Munir and Willmott 2007) depicting entrepreneurs who are quite unencumbered by socio-cultural context factors and involved in straightforward rational problem-solving (Mutch 2007). This leads, in sum, to a managerialist 
view of the creation and destruction of institutions where individuals found institutions in the same way and for the same reasons as they found companies.

It is no surprise that this twist of institutional theory sells well as it fits into the ongoing trend of the individualisation of modern society and the advance of the capitalist logic in all realms of social and academic life - a further facet of the "institutionalisation of institutionalist theory” (Tolbert and Zucker 1996), so to speak. In this respect, it is probably no coincidence that all major publication outlets for institutionalist theory are situated in the UK and the US, the two countries generally regarded the purest examples of individualist culture and neoliberal-capitalist market order.

This individualist-managerialist bias creates a number of problems. It, first, reduces institutionalist theory to a functionalist perspective in which the only place for an agent is to pull the trigger for change once all field requirements are in place. Gone are the complexities of a symbolic interactionist, phenomenological or structurationist theory of action; what remains is a deus ex machina creating the "paradox of embedded agency".

It, second, misdirects attention to heroes and successes in a linear time line (Hardy and Maguire 2008; Khan, Munir and Willmott 2007; Lawrence and Phillips 2004; Mutch 2007) and away from collective efforts, failures and repeated attempts, loops, feedbacks and interdependencies that the history of institutions is so rich in. This not only impoverishes the scholarly view on institutions, but has political and societal consequences. In this perspective, institutions tend to become tools to solve particular problems rather than ways of life and expressions of societal (sub-)cultures. And once they have become mere rational tools, they are easily subsumed under a capitalist logic of efficiency and maximisation. This, in turn, leads scholars and policy-makers to neglect the diversity and heterogeneity of interpretations, 
the variations of practices, the dynamics between actors and/or logics innate to any institution. While the "fuzzy" edges and interstices are rationalised away, institutional performance as measured by a few criteria moves to the foreground, and institutions are abolished and founded accordingly. The current debate about the criteria for university performance in the UK's new REF scheme may serve as an illustration how the institution of the university once viewed as a way of life for academics, an education for life to students, and as a location where a society's intellectual efforts were bundled - is reduced to publication output and, via “impact”, to economic interests. As I indicated before, this instrumentalist view fits long-term societal trends like Habermas's (1988) colonisation of the life-world, or, in the case of the university, Lyotard's (1994) prognosis concerning the transformation of knowledge.

Finally, and back to theoretical considerations, it leads to a logical conflation of practice and action that I will discuss in the subsequent section.

\section{The conflation of practice and action}

Whether we follow Giddens’s (1984) idea of institutions binding time and space or Clemens and Cook's (1999) insight that institutions endure: there is always a distinctly longitudinal, supra-individual aspect in the definition of institutions. Institutions are sets of practices rather than sequences of individual actions. In a direct comparison of the two terms, we may conceptualise actions as happenings observable at a specific location and time, whereas practices involve an "invisible" quality of rules or custom that goes unnoticed if one only observes one instance of it. We may observe a doctor sticking needles into a patient, but we cannot observe in the same way that she is practising acupuncture, nor if it is a example of good practice or not. Hence, actions are instantiations of a practice and the relationship between them is that of type and token or of universal and particular. As Lounsbury and 
Crumley (2007) show, individual actions may reproduce, vary or even counter a certain practice, but an individual action cannot establish, maintain or abolish a practice because a practice is made up of many actions. Even a very powerful individual actor, in establishing a new practice, must rely on other actors taking up (or being forced into taking up) a certain type of action. For this reason, Czarniawska (2009:424) has argued that the term "institutional entrepreneur”, in the case of the individual entrepreneur, is an oxymoron.

This logical distinction between universal and particular, however, is not equally important for all sociological schools. It matters a lot in schools where particular data is collected, for example in historical analysis or case studies. It matters less where types of action are discussed in a more theoretical manner, for example in functionalist sociology. Functionalist sociology, as a rule, does not bother with individual actions at all. If it does, as we have seen with Schumpeter, it subsumes individuals and individual behaviour under types so that every particular occurrence is one manifestation of the type in question. This is a logical relation that does not require further argument. In contrast, individual actions related to the creation, change or destruction of institutions require a genetic, not a logical, argument as they are concerned with an empirical-longitudinal process. It must be shown, for example, how the individual action constitutes the founding of the institution, not that it is a manifestation of the type "institution-founding practice". This argument is much more difficult to make. For the reasons given at the beginning of this section, I think it is indeed impossible to make for the individual entrepreneur. Conceptualising actors as collective or dispersed agents, on the other hand, can address the conflation problem. It may, however, struggle with others.

\section{Collective Agency, Dispersed Agency}


While functionalism and conflation remain widely undiscussed, the entrepreneurship literature has taken up the critique of the individualist-managerialist bias (albeit not of its political consequences) in recent publications. These publications then present notions of collective or dispersed agency as solutions. In my sample, it was mainly older publications (Beckert 1999; Fligstein 2001) that defined entrepreneurs as individual actors, whereas most of the more recent literature looked at collective actors (Dorado 2005; Garud, Jain and Kumaraswamy 2002; Lounsbury and Crumley 2007; Maguire and Hardy 2009; Wijen and Ansari 2007) or even the process of entrepreneurship (Perkmann and Spicer 2007; Zilber 2007). It is in fact quite instructive how, for example, Maguire and Hardy (Hardy and Maguire 2008; Maguire and Hardy 2009) change their emphasis from individual entrepreneurs to collective ones within a comparatively short time stating in their most recent publication: "We therefore suggest that a single actor is unlikely to be responsible for the success of outsider-driven deinstitutionalization or of institutional entrepreneurship more generally” (Maguire and Hardy 2009:173). However, the allure of the bias seems quite persistent, and although the proportion of studies on individual entrepreneurship has declined, the topic is far from dead (see, for example, Carney 2007; Rothenberg 2007; Svejenova, Mazza and Planellas 2007). Moreover, a switch to collective agency does not necessarily imply the abandonment of the managerialist bias, since after all, management tends to be a collective activity too. Thus older (Garud, Jain and Kumaraswamy 2002; Greenwood and Suddaby 2006) as well as more recent studies (Markowitz 2007; Santos and Eisenhardt 2009) portray organizations or other collective actors as actively managing institutional change thereby drawing on the same bias.

On a conceptual plane, collective and dispersed entrepreneurship also create a new problem. Entrepreneurs are, by Schumpeter's definition (and popular imagination), individual actors. This makes sense because their motivation rests on will and willpower, which is somewhat 
difficult to construe for a group and impossible to do for a process or dispersed actor. More importantly, however, the concept loses any meaning if we define institutional entrepreneurship as individual actors, collective actors or processes creating, changing, maintaining or destroying institutions ${ }^{1}$. In our highly institutionalized modern society it would, according to this definition, almost be impossible to not be involved in institutional entrepreneurship in every minute of one’s life. In academic terms, everything can be studied under this definition.

The review of the literature seems to confirm this suspicion. In order to avoid any bias on my part, let us go back to Leca et al. (2008) to see which insights 67 articles published in top academic journals have produced. Leca et al. focussed on two questions that their review signalled to be central: “(1) Under what conditions is an actor likely to become an institutional entrepreneur? (2) How does the process of institutional entrepreneurship unfold?” (p.6). The answers to question 1 revolve around the issue of enabling conditions on the level of the field (a topic already mentioned above), or the actors' social position within the field. As enabling conditions, Leca et al. name: Precipitating jolts or crises, the presence of acute, field-level problems as well as problems related to the scarcity of resources. The degree of heterogeneity of the field, which is a measure of the diversity of ideas and norms within a field, plays a role insofar as heterogeneous fields are in general more prone to innovation and change. The degree of institutionalization of the field also seems to be a factor although authors disagree whether it affects entrepreneurship positively or negatively. The actors' social position is important because it determines their access to resources and influences their perception of the field.

As to question 2, we learn that

\footnotetext{
${ }^{1}$ The same goes for institutional work, cf. the definition of Zietsma and Lawrence: "We examine the work of actors to create, maintain, and disrupt the practices that are considered legitimate within a field...” (Zietsma and Lawrence 2010:189).
} 
“Institutional entrepreneurs can sometimes impose institutional change on dissenting actors without having to win them over... But such situations are rare...Because they can seldom change institutions alone, institutional entrepreneurs must typically mobilize allies, develop alliances and cooperation. In particular they must mobilize key constituents such as highly embedded agents...” (p. 11).

Studying the methods institutional entrepreneurs use to achieve this, the literature has focussed on the analysis of discourse and found that:

"Such discursive frames include two major dimensions... The first, specification through framing of the existing organizational failing, includes diagnosis of the failure and assignment of blame for it. ...The second, justification of the promoted project as superior to the previous arrangement, involves the institutional entrepreneur delegitimating existing institutional arrangements and those supported by opponents...” (p. 12).

None of this seems very groundbreaking or surprising. In fact, if scholars had clubbed together in 1988, walked out on the proverbial street and asked any mildly politically skilled person, they might have got the same answers in less than half an hour. I am not pointing this out because I want to declare all these efforts futile - many of the case studies are exciting, the theoretical papers comprehensive -, but to show that a research programme without an analytical frame is just a license to print (see the introduction to this paper) and one of those bootstrapping exercises that institutional scholars normally study in fields other than their own: Something (a topic) is important because important people believe it to be important (publish a lot about it), these people being important (cited and ranked highly) because they do this important thing.

\section{Institutional Work}


In 2006, Lawrence and Suddaby (2006) went back to the concept of „institutional work“ in order to direct research away from the "hypermuscular entrepreneur", as they call it (Lawrence, Suddaby and Leca 2009). The concept has since received a great deal of attention, not least by those scholars who find the notion of the institutional entrepreneur problematic for some of the above reasons. Lawrence and Suddaby intended their notion to work as an umbrella that can link studies on institutional entrepreneurship with research on institutional change and innovation as well as deinstitutionalization (Lawrence, Suddaby and Leca 2009). Möllering (2010) also cites discourse analysis as an important strand in the new theme. The integrative outreach has its price in, again, a very vague definition of the subject as "the purposive action of individuals and organizations aimed at creating, maintaining, and disrupting institutions” (Lawrence and Suddaby 2006:17). Subsequently, however, the authors provide some more focus by stressing that their main aim is to highlight the awareness and reflexivity of actors, understanding institutions as constituted by conscious action of actors (in line with Giddens's bracketing), and conceptualising action from a practice perspective (Lawrence, Suddaby and Leca 2009:7).

Two promising directions emerge from this. One is the idea to use practice theory, as, among others, proposed by Schatzki (Schatzki, Knorr Cetina and von Savigny 2001) or Bourdieu (1990), to anchor the concept of agency theoretically. The second is to commit oneself to a strategic view of institutional action focussing on purposiveness, intentionality and reflexivity (Möllering 2010). The second direction might lead either to a rational choice model of action in which uncertainty plays a central role, or it might lead to classic theories of action in the tradition of Schütz and others. At present, however, I do not see how both directions could be theoretically combined, as seems to have been intended by Lawrence and Suddaby, given that 
one central interest of practice theory is to avoid privileging the purposive mind and instead look at the interplay of objects, activities and know-how (Reckwitz 2002).

\section{An Analytical Frame}

My critique can be summarised by the need for the institutional entrepreneur/institutional work perspective to develop an analytical frame for agency in order to produce results that go beyond case studies and plausibility. Or to rephrase Mutch (2007:1123): Instead of describing the phenomenon, we should start analysing it and examine our assumptions about the nature of agency. The concept of institutional work could provide a starting point for this if it does not lose itself in the creation of typologies and matrices developed from empirical case studies but continues to follow (one of) the focuses Lawrence, Suddaby and Leca have proposed.

An analytical frame has to be developed from a theory, and I basically see three candidates for this. Table 2 gives an overview over these options. Although I am convinced that the table contains the major hurdles to an integration of agency theories, I am aware that four sentences in each column cannot do justice to a set of theories, each of which differs from similar theories in various respects and each of which has accumulated an impressive number of shelf meters both in the original oeuvre and in the secondary literature. I would hence ask to take these descriptions only as a rough guideline to distinguishing the perspectives and as a starting point for a more sophisticated analysis that would probably then focus on one author alone.

INSERT TABLE 2 ABOUT HERE 
The first candidate are the classic action theories of Weber, Schütz, Mead, Goffman and Garfinkel, to name just the most popular. They offer rich descriptions of agency in relation to purpose, meaning, reflexivity and interaction that could be channelled to analyse entrepreneurial activities. While some of them also develop ideas on habitual action, they do not focus on practices, partly because this concept became popular only much later. The theoretical challenge is to marry them to the structuralist assumptions and macro perspective that institutionalist theory has held traditionally. The second candidate are theories that claim to have overcome the structure-agency dualism, most notably Giddens and Bourdieu, but also practice approaches inspired by Schatzki’s (Schatzki 1997; Schatzki 2000; Schatzki 2005; Schatzki, Knorr Cetina and von Savigny 2001) or Turner's (1994; 2001) work. They offer ways to overcome or circumvent the classic structure-agency dilemmas by invoking different social ontologies based on Heidegger, Wittgenstein or relational philosophy à la Leibniz (Weik 2006). They often take practices as their point of departure, but do not, with the exception of Giddens, dwell much on classical issues of agency. These theories would have to be adapted and refined with regard to institutional core issues and tenets that they have mostly neglected in their original versions. The third candidate is neo-institutionalism's own brand of agency theory (Meyer, Boli and Thomas 1987; Meyer and Jepperson 2000). Here, naturally, compatibility with the overall framework is guaranteed. These approaches would, however, have to be enriched by classic issues of agency theory like purposiveness, intention, free will, to name just a few. One possible line of development here is Mohr's (Mohr and Duquenne 1997; Mohr 1998; Mohr and Friedland 2008; Mohr and Harrison 2008) work on networks, culture and meaning as well as Padgett and McLean’s (2006) network study. For a less model-oriented approach, Friedland (2009) has provided quite interesting suggestions concerning a "phenomenology of practice” along with a critique of Bourdieuan field theory. 
Lurking behind all three options is the structure-agency problem; this can probably not be remedied given the need to theorise both actors and institutions. However, an analytical frame is not a full-blown theory, so one might get away with some ambiguity or "bricolage".

\section{Summary}

Starting from a critique of the individual institutional entrepreneur, I have examined if notions of collective or dispersed agency suffice to establish an agency perspective in institutionalist theory. I have found that they, while addressing some of the shortcomings of the individual entrepreneur, run the risk of explaining everything until they explain nothing. Hence, I argue, a theoretical framework is needed that limits (but also enables) research on agency in institutional contexts. As a starting point to develop such a framework, I propose three perspectives that each have their individual strengths and weaknesses. 
Battilana, 2006,

Beckert, 1999,

Child et al., 2007,

Clemens and Cook, 1999,

Dorado, 2005,

Fligstein, 2001,

Garud et al., 2002,

Garud et al., 2007,

Greenwood and Suddaby, 2006,

Khan et al., 2007,

Lawrence and Phillips, 2004,

Levy and Scully, 2007,

Lounsbury and Crumley, 2007,

Maguire and Hardy, 2009,

Misangyi et al., 2008,

Mutch, 2007,

Perkmann and Spicer, 2007,

Phillips et al., 2004,

Rao and Giorgi, 2006,

Suddaby and Greenwood, 2005,

Wijen and Ansari, 2007,

Zilber, 2002,

Zilber, 2007

Table 1: Analysed Publications 


\begin{tabular}{|l|l|l|l|}
\hline & $\begin{array}{l}\text { Classic Theories of } \\
\text { Action }\end{array}$ & $\begin{array}{l}\text { “Non-dualist” } \\
\text { Theories }\end{array}$ & $\begin{array}{l}\text { Institutionalist } \\
\text { Action Theory }\end{array}$ \\
\hline Promise & $\begin{array}{l}\text { Rich description of } \\
\text { agency }\end{array}$ & $\begin{array}{l}\text { Structure-agency } \\
\text { dualism overcome }\end{array}$ & $\begin{array}{l}\text { Integrated in } \\
\text { institutionalist theory }\end{array}$ \\
\hline Challenge & $\begin{array}{l}\text { Integration with } \\
\text { macro/structuralist } \\
\text { perspective of } \\
\text { institutionalist theory }\end{array}$ & $\begin{array}{l}\text { Modification with } \\
\text { regard to } \\
\text { institutionalist core } \\
\text { issues }\end{array}$ & $\begin{array}{l}\text { Integration of classic } \\
\text { action themes like } \\
\text { purpose etc. }\end{array}$ \\
\hline $\begin{array}{l}\text { Position vis-à-vis } \\
\text { reflexivity and } \\
\text { strategic action }\end{array}$ & Integral part of theories & $\begin{array}{l}\text { Little focus on } \\
\text { purposive action, often } \\
\text { analysed as } \\
\text { bracketed/separate }\end{array}$ & $\begin{array}{l}\text { Only included with } \\
\text { regard to legitimacy } \\
\text { of actors }\end{array}$ \\
\hline $\begin{array}{l}\text { Position vis-à-vis } \\
\text { practices }\end{array}$ & $\begin{array}{l}\text { Little focus on } \\
\text { practices, although } \\
\text { habitual action treated }\end{array}$ & Integral part of theories & $\begin{array}{l}\text { Suggests itself as } \\
\text { focus although not } \\
\text { explicitly treated }\end{array}$ \\
\hline
\end{tabular}

Table 2: An Overview of the Perspectives 


\section{References}

Battilana, Julie. 2006. "Agency and Institutions: The Enabling Role of Individuals' Social Position." Organization 13(5):653-76.

Battilana, Julie, and Thomas D'Aunno. 2009. "Institutional Work and the Paradox of Embedded Agency." Pp. 29-58 in Institutional Work, edited by Thomas Lawrence, Roy Suddaby, and Bernard Leca. Cambridge: Cambridge University Press.

Beckert, Jens. 1999. "Agency, Entrepreneurs, and Institutional Change." Organization Studies 20(5):777-99.

Bourdieu, Pierre. 1990. The Logic of Practice. Stanford: Stanford University Press.

Carney, Michael. 2007. "Institutional Entrepreneurship and the Transformation of the Global Air Navigation Regime." Academy of Management Proceedings.

Child, John, Yuan Lu, and Terence Tsai. 2007. "Institutional Entrepreneurship in Building an Environmental Protection System for the People's Republic of China." Organization Studies 27(7):1013-34.

Clemens, Elisabeth, and James Cook. 1999. "Politics and Institutionalism: Explaining Durability and Change." Annual Review of Sociology 25:441-66.

Czarniawska, Barbara. 2009. "Emerging Institutions: Pyramids or Anthills?" Organization Studies 30(4):423-41.

DiMaggio, Paul. 1988. "Interest and Agency in Institutional Theory." Pp. 3-21 in Instititutional Patterns and Organizations, edited by Lynne Zucker. Cambridge (Mass.): Ballinger Publishing Company.

Dorado, Silvia. 2005. "Institutional Entrepreneurship, Partaking, and Convening." Organization Studies 26(3):385-414.

Emirbayer, Mustafa, and Ann Mische. 1998. "What Is Agency?" American Journal of Sociology 103(4):962-1023.

Fligstein, Neil. 2001. "Social Skill and the Theory of Fields." Sociological Theory 19(2):10525.

Friedland, Roger. 2009. "Institution, Practice, and Ontology: Toward a Religious Sociology." Pp. 45-83 in Research in the Sociology of Organization, edited by Peter Walgenbach, Renate Meyer, Kerstin Sahlin, and Marc Ventresca. Bingley: Emerald.

Garud, Raghu, Cynthia Hardy, and Steve Maguire. 2007. "Institutional Entrepreneurship as Embedded Agency: An Introduction to the Special Issue." Organization Studies 27(7):957-69.

Garud, Raghu, Sanjay Jain, and Arun Kumaraswamy. 2002. "Institutional Entrepreneurship in the Sponsorship of Common Technological Standards: The Case of Sun Microsystems and Java." Academy of Management Journal 45(1):196-214.

Giddens, Anthony. 1984. The Constitution of Society. Berkeley: University of California Press.

Greenwood, Royston, and Roy Suddaby. 2006. "Institutional Entrepreneurship in Mature Fields: The Big Five Accounting Firms." Academy of Management Journal 49(1):2748.

Habermas, Jürgen. 1988. Theorie des kommunikativen Handelns. Frankfurt/Main: Suhrkamp.

Hardy, Cynthia, and Steve Maguire. 2008. "Institutional Entrepreneurship." Pp. 198-217 in The Sage Handbook of Organizational Institutionalism, edited by Royston Greenwood, Christine Oliver, Roy Suddaby, and Kerstin Sahlin. Los Angeles: Sage.

Khan, Farzad, Kamal Munir, and Hugh Willmott. 2007. "A Dark Side of Institutional Entrepreneurship: Soccer Balls, Child Labour and Postcolonial Impoverishment." Organization Studies 27(7):1055-77. 
Lawrence, Thomas, and Nelson Phillips. 2004. "From 'Moby Dick' to 'Free Willy': MacroCultural Discourse and Institutional Entrepreneurship in Emerging Institutional Fields." Organization 11(5):689-711.

Lawrence, Thomas, and Roy Suddaby. 2006. "Institutional Work." Pp. 215-54 in Handbook of Organization Studies, edited by Stewart Clegg, Cynthia Hardy, Thomas Lawrence, and Walter Nord. London: Sage.

Lawrence, Thomas, Roy Suddaby, and Bernard Leca. 2009. "Introduction: Theorizing and Studying Institutional Work." Pp. 1-27 in Institutional Work, edited by Thomas Lawrence, Roy Suddaby, and Bernard Leca. Cambridge: Cambridge University Press.

Leca, Bernard, Julie Battilana, and Eva Boxenbaum. 2008. "Agency and Institutions: A Review of Institutional Entrepreneurship." Working Paper.

Levy, David, and Maureen Scully. 2007. "The Institutional Entrepreneur as Modern Prince: The Strategic Face of Power in Contested Fields." Organization Studies 27(7):971-91.

Lounsbury, Michael, and Ellen Crumley. 2007. "New Practice Creation: An Institutional Perspective on Innovation." Organization Studies 28(7):993-1012.

Lyotard, Jean-Francois. 1994. Das postmoderne Wissen. Wien: Passagen-Verlag.

Maguire, Steve, and Cynthia Hardy. 2009. "Discourse and Deinstitutionalization: The Decline of DDT." Academy of Management Journal 52(1):148-78.

Markowitz, Linda. 2007. "Structural Innovators and Core-Framing Tasks: How Socially Responsible Mutual Fund Companies Build Identity Among Investors." Sociological Perspectives 50(1):131-53.

Meyer, John, John Boli, and George Thomas. 1987. "Ontology and Rationalization in the Western Cultural Account." Pp. 12-37 in Institutional Structure, edited by George Thomas, John Meyer, F.O. Ramirez, and John Boli. Newbury Park: Sage.

Meyer, John, and Ronald Jepperson. 2000. "The 'Actors' of Modern Society: The Cultural Construction of Social Agency." Sociological Theory 18(1):100-20.

Misangyi, Vilmos, Gary Weaver, and Heather Elms. 2008. "Ending Corruption: The Interplay among Institutional Logics, Resources, and Institutional Entrepreneurs." Academy of Management Review 33(3):750-70.

Mohr, John, and Vincent Duquenne. 1997. "The Duality of Culture and Practice: Poverty Relief in New York City 1888-1917." Theory \& Society 26:305-56.

Mohr, John W. 1998. "Measuring Meaning Structures." Annual Review of Sociology 24(ArticleType: research-article / Full publication date: 1998 / Copyright (C) 1998 Annual Reviews):345-70.

Mohr, John W., and Roger Friedland. 2008. "Theorizing the Institution: Foundations, Duality, and Data." Theory and Society 37(5):421-26.

Mohr, John W., and C. White Harrison. 2008. "How to Model an Institution." Theory and Society 37(5):485-512.

Möllering, Guido. 2010. "Collective Market-Making Efforts at an Engineering Conference." MPIFG Discussion Paper 10(2).

Mutch, Alistair. 2007. "Reflexivity and the Institutional Entrepreneur: A Historical Exploration." Organization Studies 27(7):1123-40.

Padgett, John F, and Paul D McLean. 2006. "Organizational Invention and Elite Transformation: The Birth of Partnership Systems in Renaissance Florence." The American Journal of Sociology 111(5):1463-568.

Perkmann, Markus, and André Spicer. 2007. "'Healing the Scars of History': Projects, Skills and Field Strategies in Institutional Entrepreneurship." Organization Studies 27(7):1101-22.

Rao, Hayagreeva, and Simona Giorgi. 2006. "Code Breaking: How Entrepreneurs Exploit Cultural Logics to Generate Institutional Change." Resarch in Organizational Behavior 27:269-304. 
Reckwitz, Andreas. 2002. "Toward a Theory of Social Practices." European Journal of Social Theory 5(2):243-63.

Rothenberg, Sandra. 2007. "Environmental Managers as Institutional Entrepreneurs." Journal of Business Research 60:749-57.

Santos, Filipe, and Kathleen Eisenhardt. 2009. "Constructing Markets and Shaping Boundaries: Entrepreneurial Power in Nascent Fields." Academy of Management Journal 52(4):643-71.

Schatzki, Theodore. 1997. "Practices and Actions. A Wittgensteinian Critique of Bourdieu and Giddens." Philosophy of the Social Sciences 27(3):283ff.

Schatzki, Theodore. 2000. "The Social Bearing of Nature." Inquiry 43:21-38.

Schatzki, Theodore. 2005. "The Sites of Organizations." Organization Studies 26(3):465-84.

Schatzki, Theodore, Karin Knorr Cetina, and Eike von Savigny. 2001. The Practice Turn in Contemporary Theory. London: Routledge.

Schumpeter, Joseph. 1934. Theorie der wirtschaftlichen Entwicklung. Berlin: Duncker \& Humblot.

Seo, Myeong-Gu, and W.E. Douglas Creed. 2002. "Institutional Contradictions, Praxis, and Institutional Change: A Dialectical Perspective." Academy of Management Review 27(2):222-47.

Suddaby, Roy, and Royston Greenwood. 2005. "Rhetorical Strategies of Legitimacy." Administrative Science Quarterly 50:35-67.

Svejenova, Silviya, Carmelo Mazza, and Marcel Planellas. 2007. "Cooking Up Change in Haute Cuisine: Ferran Adrià as an Institutional Entrepreneur." Journal of Organizational Behavior 28:539-61.

Tolbert, Pamela, and Lynne Zucker. 1996. "The Institutionalization of Institutional Theory." Pp. 175-90 in Handbook of Organization Studies, edited by Stewart Clegg, Cynthia Hardy, and Walter Nord. London: Sage.

Turner, Stephen. 1994. The Social Theory of Practices. Cambridge: Blackwell.

Turner, Stephen. 2001. "Throwing out the tacit rule book: learning and practice." Pp. 120-30 in The Practice Turn in Contemporary Theory, edited by Theodore Schatzki, Karin Knorr Cetina, and Eike von Savigny. London: Routledge.

Weik, Elke. 2006. "Working Relationships. A Meta-View on Structure and Agency." Theory \& Science 7(1).

Wijen, Frank, and Shahzad Ansari. 2007. "Overcoming Inaction through Collective Institutional Entrepreneurship: Insights from Regime Theory." Organization Studies 27(7):1079-100.

Zietsma, Charlene, and Thomas Lawrence. 2010. "Institutional Work in the Transformation of an Organizational Field." Administrative Science Quarterly 55:189-221.

Zilber, Tammar. 2002. "Institutionalization as an Interplay Between Actions, Meanings, and Actors: The Case of a Rape Crisis Center in Israel." Academy of Management Journal 45(1):234-54.

Zilber, Tammar. 2007. "Stories and the Discursive Dynamics of Institutional Entrepreneurship: The Case of Israeli High-tech after the Bubble." Organization Studies 27(7):1035-54. 